\title{
8
}

\section{Philosophy: Reciprocity BetWeen The Most Private \\ AND THE Public}

According to the account given in the previous chapter, true friendship entails being morally virtuous to oneself and to others. But because Aristotle advocates exercising intellectual virtue at least as much as moral virtue, one wonders whether he thinks a human being can exercise moral and intellectual virtue at the same time. Can a human being engage in the activity of philosophy or lead the contemplative life and maintain human relationships? Can friends even philosophize together? Finally, one wonders, is friendship perhaps even necessary to philosophy? In this chapter I try to answer these questions and, more generally, to explain what Aristotle means by the activity of contemplation or philosophy. ${ }^{1}$ Thus, it begins with his discussion of the intellectual virtues.

\section{INTELlECTUAL ViRTUE AND CONTEMPLATION}

The intellectual virtues fall into two categories: faculties and qualities (NE VI). The intellectual faculties are mechanical aptitude, which may develop into technical skill (technē); scientific aptitude or knowledge (epistēmē), the ability to understand and use scientific, including mathematical, truths in problem solving; prudence (phronessis); wisdom (sophia); and intuitive reason, or mind (nous), the last two faculties of which require some discussion ( $N E$

1 See Chapter 6, note 55, pp. 159-60. 
1139b16-17). The other intellectual virtues may characterize these faculties: deliberative excellence (euboulia) should characterize prudential decision making; understanding or comprehension (sunesis) allows one to follow reasoning and can thus supplement both scientific aptitude and prudence; and judgment (gnōmē), a sense for what is fair in human matters, is an aspect of prudence ( $N E$ 1142b31-33, 1143a11-24, 29-31).

Nature ranks the faculties according to what each grasps. The faculties that concern what varies rank lower in nature than those that apprehend what does not vary, for in nature that which is constant maintains order, whereas that which comes into being and passes away merely shares in it; and what maintains order partakes more directly in the divine or supreme good (to ariston) (Met 1075a11-15). The lower intellectual virtues, then, are technical skill and prudence, for the variable includes "both things made and actions done" (NE 1140a1-2). The higher virtues are scientific knowledge, wisdom, and intuitive reason, for the objects of these do not come into being and pass away: the object of scientific knowledge is that in nature which, demonstrably, never changes (for example, the life cycles of plants and animals, the constellations of the stars, the composition of air); intuitive reason apprehends "the first principle from which what is scientifically known follows"; and wisdom is intuitive reason and scientific knowledge combined (NE 1139b22-24, 31-32, 1140b33-34, 1141a18-20). A human being must, it appears, have and engage these higher virtues in order to be by nature excellent.

There is, however, a natural hierarchy even among the higher intellectual virtues; hence, to be truly excellent one must have the highest of them-wisdom (NE 1141a16-17). Since scientific knowledge is a part of wisdom, it is probable that some understanding of modern science, such as its findings on human health and longevity (since nothing incomplete belongs to happiness; ${ }^{2}$ NE 1177b2526), would be subsumed under wisdom. But knowledge of the demonstrable constants of nature is knowledge of only one kind of constancy, and not of the most honorable kind (1141b2--3). Indeed, scientific knowledge is defective by its own measure: it establishes truth by revealing the cause or rational ground of every effect, but

2 See also Chapter 7, note 9, especially p. 178. 
it must itself presuppose the rational ground of this method, that is, of reason (1139b28-29), as Kant also observed. And although intuitive reason apprehends the source of all scientific constancy, which is not itself demonstrable, and therefore ranks higher in nature than scientific knowledge, what accounts for scientific constancy is still in some sense only a part of nature. To be wise is to have knowledge of the whole of nature, of what is demonstrable and indemonstrable (1140b33-1141a8).

But to indicate that one can know what is indemonstrable contravenes the widely accepted modern epistemological claim that one can have knowledge only of what exists and can know what exists only by demonstrating its existence. What, according to Aristotle, both has being and is indemonstrable? One might infer that the answer is God-that is, Aristotle's prime mover. Aristotle explains, however, that wisdom is not concerned "with the causes described in the Physics. It is not concerned with the final cause; for this is the Good, and this belongs to the sphere of action and to things which are in motion; and it is this which first causes motion. . . . but there is no Prime Mover in the sphere of immovable things" (Met 1059a34-38).

According to Aristotle, speculative reason itself is, and yet it is not of the physical world. Intuitive reason is the ability to think about thinking (noêsis noēseōs). In contrast to "scientific knowledge [epistēmē] and perception [aisthēsis] and opinion [doxa] and [calculative] thought [dianoia]" which "are apparently always of something else, and only incidentally of themselves," the object of intuitive reason is thinking itself (Met 1074b35-36). ${ }^{3}$ Although intuitive reason is the only always self-conscious faculty-the only faculty whose sole work is to understand or define reasonscientific knowledge or aptitude, the other speculative faculty, is self-reflective insofar as its object is theory, definition, or truth. Similarly, if one abstracts the matter from the objects of the nonspeculative or productive faculties, one is left with pure thought or definition (for example, the perception of Argos the dog becomes the concept of dog). When definitive knowledge is the object of thinking, one is thinking about thought (Met 1074b37-1075a5).

3 The human mind ordinarily "knows itself [only] in so far as it is conscious of its object"; see Klaus Oehler, "Aristotle on Self-Knowledge," Proceedings of the American Philosophical Society 118, no. 6 (1974), 498. 
As both Richard Bodéüs and Klaus Oehler stress, Aristotle thinks that a human being can become one with the divine being or prime mover only insofar as the activity of thinking thought is also its activity. One can transcend human consciousness only by imitating, not "grasping" or "beholding," the divine 4 (this is what Aristotle means by saying that wisdom is not concerned with the prime mover). As Oehler explains, "the mistaken view" is "that the self-reflection of the Nus [nous], since as actualized Nus it is identical with the intelligible forms, consists in the thinking of those intelligible forms." In fact, "[Aristotle] is not saying . . . that when the Nus is thinking itself it is thinking some particular content; he is saying that the Nus, in thinking its objects, experiences the self-reflection inherent in all thinking and so experiences itself." 5

One cannot remain like the divine-and thus become divine, or immortal—because "happiness is a kind of activity; and an activity clearly is something that comes into being, not a thing that belongs [to one all the time], like a piece of property" (NE 1169b29-30). "Human finitude does not allow us to remain, like the Prime Mover, in a permanent state of Energeia." We can only aspire to, never attain, "la Vie de Dieu."6

Yet earthly existence does not entirely handicap the activity of thinking about thinking, for consciousness is not possible without the world of action and objects. The intellect cannot perceive that it is perceiving unless it has something outside itself to perceive. As Oehler puts it, "the perceptible seems to be prior to perception" (and thus to awareness of perception or consciousness). Insofar as the intellect cannot either perceive or perceive itself without the world - and thus without being in such a world - the intellect and body are for Aristotle one (he is thus not the ancestor of Descartes). ${ }^{7}$

4 Bodéüs, "Notes sur quelques aspects de la conscience dans la pensée aristotélicienne," Phronesis 20, no. 1 (1975), 73.

5 Oehler, "Aristotle on Self-Knowledge," 497-98; see also 495-96. Bodéüs makes the same point at "Notes," 73.

6 Oehler, "Aristotle on Self-Knowledge," 499; Bodéüs, "Notes," 73-74.

7 Oehler, "Aristotle on Self-Knowledge," 496. Seealso Bodéüs, "Notes," 68: "It is important to observe that consciousness can accompany the most banal of actions: walking, for example . . . and that all acts are not automatically conscious." Hence, Aristotle says, "we can perceive that we are perceiving." 
Ordinary consciousness differs from the consciousness of the wise man who thinks about being conscious. In being aware of his ability to think about his thinking, he is conscious of "his own perfection." 8 As Aristotle explains,

there is something which perceives [to aisthanomenon] that we are active. Hence, if we are perceiving, we perceive that we are perceiving; and if we are thinking [noomen], we perceive that we are thinking. Now perceiving that we are perceiving or thinking is the same thing as perceiving that we are, since we agreed that being is perceiving or thinking [to gar einai èn aisthanesthai é noein]. (NE 1170a30-b1)

But why should we think about thinking? Because it is living, not only according to what is highest in us, which is the human function, but engaging what is highest with what is highest, namely, itself (Met 1072b18-24; NE 1098a7-17, 1170a16-19). This self-engagement is superior to the activity of thinking about anything else because reason's function is to be active (energei), and it is most active and thus functioning best when contemplating itself (theoria). ${ }^{9}$ Thus, Aristotle points out, it is the activity of thinking about thinking, not the capacity to think about thinking, which is divine, or approaches divinity. Strictly speaking, possession of a human mind does not make human beings worthy of the characterization 'part-divine'; only their exercise of that mind to its capacity, in contemplation, does. And only contemplation bestows true happiness. As Bodéüs explains, the realization that we are equipped to think about thinking - that we are in this sense perfect beingsgives us immense pleasure. Actualizing our perfection in noetic activity thus makes us happy. ${ }^{10}$

Human beings should aspire to experience perfection also because it illuminates the range of human virtue. To understand the possibilities of human virtue and demonstrable nature's resistance to them is to have wisdom, "the most exact of the forms of knowl-

8 Bodéüs, "Notes," 70.

9 Oehler explains: "The Nus knows itself by means of its participation in the nature of its object. The nature of its object is to be knowable. When the Nus participates in it, it assumes the nature of its object, which thereby becomes common to both" ("Aristotle on Self-Knowledge," 499).

10 "Notes," 69-70. 
edge" (NE 1141a17) and the knowledge that should guide political order. ${ }^{11}$

\section{The Relation between Moral and INTELLECTUAL VIRTUE}

If happiness lies in engaging nous - not only the intellectual part of us but a part of that part-then how can happiness be also "an activity of the soul in accordance with complete virtue [kat'aretēn teleian]" (NE 1102a5)? Happiness can be both, it seems, only if exercising the speculative intellect somehow presupposes or entails exercising the remaining virtues-prudence and the virtues of character.

Aristotle seems to give two contradictory accounts. On the one hand, he claims that the exercise of nous is itself complete-it is self-sufficient (autarkes). It seems to be necessarily so, since the excellence of the mind is separate from matter, or the body (he de tou nou kechōrismene) ), and "nothing incomplete is proper to happiness" (NE 1178a22, 1177b25-29). Contemplative activity, its object not being human beings or divisible, does not evidently need assistance from prudence. Nor does it need the assistance of the other various moral virtues-such as generosity, courage, and moderation-since it does not require, and even seems to exclude, interaction with human beings (1178a9-14). In particular, it seems not to need moderation, since thinking is the most active and thereby extreme of all activities (Pol 1325b16-21; NE 1177a19-21, b20-21).

On the other hand, Aristotle suggests that exercising nous does in fact presuppose the moral virtues. He claims that prudence aims to bring wisdom into being as medical science aims to bring health into being (NE 1145a6-9) and that prudence "cannot reach its fully developed state without virtue" (1144a29-30, 1178a16-19)—since moral virtue "makes us aim at the right mark, and prudence makes us take the right means" (1144a7-9). It can be inferred that a human being led by appetites and desires cannot think about thought. But what is equally clear and makes Aristotle's claims problematic is that a human being cannot, according to Aristotle's

11 See Chapter 6, “Leisure: Public and Private Good," pp. 163-64. 
description, contemplate and simultaneously exercise the moral virtues toward others. Thus, as A. W. H. Adkins explains, Aristotle's meaning must be as follows:

The theoretikos will indeed possess all the aretai: they are needed to render him a good specimen of human being (1144a1 ff.), and an absence of well-established moral dispositions would distract him from his theoria. However, any arete can exist in a state either of hexis or of energeia; one cannot exercise both theoria and any practical arete at the same time; and for the well-being of the theoretikos it suffices that he possess the other aretai in a state of hexis for so long as he is able to exercise his theoria uninterruptedly. ${ }^{12}$

We must speculate, however, about why Aristotle thinks that philosophers should be good specimens of human being. It seems that a philosopher should have at least a good reputation, that is, should be a good citizen and morally virtuous enough to teach. A philosopher who does not obey the laws risks, as does any other person, incarceration, ostracism, or execution. But such a philosopher also risks the reputation of all philosophers and philosophy. Indeed, one instance of a philosopher being uncivil might be sufficient for a political order to prohibit philosophy. A philosopher who is not civil enough to teach, to whom no one listens, fails to provide for the future of philosophy. The Socratic question Aristotle perhaps wishes to bring to mind is, to what extent can one appear morally virtuous without being so?

Aristotle suggests that a philosopher needs more than a good reputation insofar as he needs friends to philosophize well: "The solitary person has a hard life; for by oneself it is not easy to be continuously active, but with others and toward others it is easier" (NE 1170a5-6). Being excellent, a philosopher naturally seeks another excellent person for a friend, since excellent people find what is good by nature "good and pleasant in itself" (1170a13-16, $1179 \mathrm{~b} 21-23)$; the philosopher seeks companionship that facilitates rather than impedes philosophizing (1177a34).

Two can pursue wisdom together because, although thinking is a divine activity, it is also a human activity; as with any other human activity, one who engages in it well can help another do so. Indeed,

12 "Theoria versus Praxis in the Nicomachean Ethics and the Republic," Classical Philology 73, no. 4 (1978), 301. 
the more often the good meet, the greater friends they become, for they not only share the same activities but correct and learn from each other, each imitating "what in the other he approves of" (NE 1172a10-13). One who seeks to think correctly about thought or to find truth chooses a friend, then, not for moral sustenance or because of his moral virtue but because of his intellectual virtue. Moreover, if excellent men agree that the best way to spend their lives is in philosophizing together (sumphilosophousin) (1172a1-8), then they are willing to suspend or reconsider their differences, convictions, or individuality. Thus, to philosophize together must be to try to persuade not for the sake of one's own convictions but for the sake of truth. A genuine philosopher is, then, prepared to abandon or modify his claims.

By indicating that "sharing in discussion and thought [koinōnein logōn kai dianoias]" characterizes both friendship (NE 1170b10-12) and philosophy, Aristotle implies that friendship can be the midwife of truth. And in this way he, like Socrates, "calls philosophy down from heaven." What is more, in establishing friendship as a means to truth, Aristotle intimates that truth concerns what is good or right for human beings. In other words, one can, beyond thinking and sharing thoughts, partake in and share the truth with others. ${ }^{13}$

Yet does not truth's human accessibility indicate its variability over time? Would not the continuous mediation of the truth by human reason distort the truth? Would not 'the truth' come to reflect in fact the needs and concerns of every age? According to Aristotle, truth's safeguard against distortion is its accessibility only or fully to select human beings. Truth seems to lie somewhere between heaven and earth (NE 1134b18-1135a5), to be "the quotient of the simply good and the ancestral."14 Aristotle is admitting, in the spirit of the philosopher who returns to the cave, "that what is intrinsically or by nature the highest is not the most urgent for man, who is essentially an 'in-between' being-between the brutes and the gods." 15 The philosophical truth, or natural right, is

13 Aristotle belongs to the Socratic tradition in that "Socrates is said to have been the first who called philosophy down from heaven and forced it to make inquiries about life and manners and good and bad things. . . . he is said to have been the founder of political philosophy"; Leo Strauss, Natural Right and History (Chicago: University of Chicago Press, 1953), 120.

14 Ibid., 153.

15 Ibid., 152. 
political in that it lends itself to political adaptation. ${ }^{16}$ But it is also political in being elusive.

Philosophers following Aristotle challenge his view of natural right. Kant's moral philosophy attempts to redignify or impute greater moral weight to reason. ${ }^{17}$ Aristotle and Kant agree that the domain of reason is more real than practical experience in that contemplation is experience of the whole. Kant leaves Aristotle, however, in arguing that moral choice must occur at the noumenal level: to be moral, human beings must follow directives issuing from the domain that is independent of conditional constraints; they can apprehend those directives by hypothetically universalizing human conduct.

But what compels a person to apprehend them? Kant answers, belief in the Idea of freedom. Belief in an unconditioned totality is the law of all moral laws, for the Idea provides the connection of ends pure reason demands and is thus in the service of pure reason. Standing as a regulative principle of reason, the unconditioned totality is not thinkable as are the categories over which it presides. Being unthinkable, man can never know the Idea-for example, through the activity of philosophy-and so must hold the conviction that a perfect unity exists.

Belief in the perfection of the noumenal requires a human being to imitate it in conduct, not in thought, by enacting universalizable principles. Overcoming the tension between the noumenal and the phenomenal by way of the noumenal is the passage to freedom.

16 Put another way, "there is no fundamental disproportion between natural right and the requirements of political society, or there is no essential need for the dilution of natural right. . . . A right which necessarily transcends political society, [Aristotle] gives us to understand, cannot be the right natural to man, who is by nature a political animal" (Strauss, Natural Right, 156). Likewise, as Richard Kennington observes, the "concreteness" of the instantiation of natural right defeats eliciting an "abiding and univocal meaning." Classical natural right thus contrasts with Stoic natural law, which "is problematic because it is trans-political and therefore politically useless, at least in its undiluted form; and because its theological and teleological requirements are not easily satisfied by philosophy"; see "Strauss's Natural Right and History," Review of Metaphysics 35, no. 1 (1981), 59, 78-79.

17 The following remarks on Kant derive from his Critique of Pure Reason, unabridged ed., trans. Norman Kemp Smith (New York: St. Martin's Press, 1965); “On the Common Saying: 'This May Be True in Theory, but It Does Not Apply in Practice," and "Perpetual Peace: A Philosophical Sketch," in Kant's Political Writings, ed. Hans Reiss, trans. H. B. Nisbet (Cambridge: Cambridge University Press, 1970), 61-72, 116-30; and Foundations of the Metaphysics of Morals, trans. Lewis White Beck (New York: Bobbs-Merrill, 1959). 
Being the commands of reason, freedom is knowable to all. ${ }^{18}$ Aristotle maintains not only that most human beings cannot understand wisdom but that prudence must mediate or transform its dictates into conduct. So, although he thinks that the commands of wisdom should guide political order, he does not think that they can, as Kant hopes, replace judgment.

This is not to say that Kant does not recognize the need for judgment. But he finds the need in matters of justice, where the upholding of principles often fails and calls for response to the advisement of hypothetical imperatives. This implies, according to Kant, in contrast to Aristotle, that in the realm of justice one cannot err. Yet Kant presents the contrast between the realms of justice and morality, not in order to encourage us to lower our standards for political life, but to persuade us not to exchange duty for expediency. In his view, justice should not overrule morality, prudence should not overrule duty. ${ }^{19}$

One might say that Kant, in advocating the direct application of pure reason in practice, advocates collapsing the public-private distinction. Private standards (of reason) should become public standards (of conduct). Disjunction signals failure on the part of the public, or politics, to meet the imperatives of reason. By contrast, Aristotle argues that wisdom is recognition and preservation of the tension between the requirements of the truly private, thought thinking itself, and those of the public. Wisdom, or natural right, is not so much the compromise between private perfection and public imperfection as the understanding of public perfection or political goodness through private perfection. ${ }^{20}$ Knowledge of the unchanging standards of human excellence includes the insight that the ultimate standard is good judgment.

\section{PhilosophicAl INQUiRY}

Aristotle differs conspicuously from Kant on topics other than natural right as well. Kant believes that we must begin with pure

18 Kant, Metaphysics of Morals, 20; see also 47-49; Ronald Beiner, Political Judgment (Chicago: University of Chicago Press, 1983), 66.

19 "Perpetual Peace," 115-16, 122-25, 130; "On the Common Saying," 62, 80-83. See also Beiner, Political Judgment, 63-66.

20 Similarly, Kennington says that "the emphatically political character of classic natural right required that the wisdom of the highest human type, for which the society has the greatest need, be harmonized with the inability of the non-wise to recognize that wisdom" ("Strauss's Natural Right," 77). 
reason and aim toward its practical employment; Aristotle thinks that we should begin with opinion and aim toward truth or pure reason. Not all opinions are worthy of dialectical inquiry, of course. Opinions that are not accepted either "by the majority or by the wise" are not "reputable" but merely "contentious" (Top 100b1101a4, 104a4-15). Moreover, generally speaking, reputable opinions take the form of ethical, logical, or scientific propositions (105b19-25). Just as a doctor does not employ every method to heal, so a philosopher does not pursue every opinion (101b5-10, 104b3-5). By the same token, the philosopher should not overlook or dismiss any possibly reputable opinions (101b9-10). The philosopher must begin with what is available and accessible and has a great ability (nous) to see the truth; but he cannot see it all at once, all of a sudden. As Socrates demonstrates in the Republic, only by pressing opinions to their conclusions can one ascend out of the realm of opinion and into the realm of truth, thereby acquiring a different perspective of the former.

If opinion or the city is the subject of or feeds philosophy, then must not philosophy be subordinate to it? On the one hand, insofar as philosophy must begin with ethical propositions or politics and philosophers must be educated in the city, politics holds architectonic supremacy over even philosophy. On the other hand, philosophical activity becomes self-sufficient the moment it questions opinion. Moreover, insofar as philosophers arrive at an understanding of the whole that citizens, rulers, and legislators cannot have, they are superior to them. Hence, Aristotle concludes, to say that politics rules philosophy because philosophers are human beings is like claiming that because human beings rule the city they rule the gods (NE 1145a10-11). At the same time, in pointing out that the subject of philosophy includes the political Aristotle reveals that, from the theoretical or comprehensive vantage point of the philosopher, a dynamic equilibrium between politics and philosophy exists.

Aristotle would perhaps point out at this juncture that dialectical inquiry cannot proceed without skepticism. The philosopher's epistemic privilege should not be mistaken for possession of the truth or omniscience. ${ }^{21}$ According to Aristotle and Socrates before

21 Aristotle does not attribute omniscience to even the most perfect being of all, the prime mover. Oehler speculates that this is because Aristotle "noticed the tremendous numbers of complications connected with the question, whether immutability and omniscience are logically consistent or not, and for him there were no 
him, the genuine philosopher does not claim to have certain knowledge, being keenly aware that, as part political and part divine, he is not wholly suited for truth seeking. The philosopher's skepticism is then both auxiliary and nemesis: it simultaneously prompts relentless questioning after certainty and encourages the dismissal, as unreasonable, of any understanding of certainty. In Aristotle's eyes, a philosopher who forecloses the possibility of truth becomes, thereby, a naysaying cynic.

What enables a philosopher to be at once skeptical and open to the possibility of truth? The experience of appearances should be sufficient to compel skepticism, whereas dialectical discovery should compel an openness to the possibility of truth. Again, such openness must mean, operatively, acceptance of appearances (which may take the form of reputable opinions) as possible guides to truth. The constant apparently provides only the changing as means to its discovery. A philosophical disposition, then, keeps the world of appearance as its friend and ally while quietly resisting its attempts to seduce and divert it.

An inescapable desire to find coherence between the moral and the intellectual, the practical and the theoretical, the human and the divine, thus keeps alive a philosophical disposition. Philosophy insists on the evidential appeal of its dialectical discoveries. Yet, according to Aristotle, being unable to resolve completely the dissonance between the human and the divine does not discourage the genuinely philosophical human being; in fact, it assures that the divine is still in sight, that the philosophizing continues.

\section{PRIVACY}

In Book X, chapters 7 and 8, of the Nicomachean Ethics, Aristotle makes clear, with liberal use of superlatives, the exceptional nature of the philosopher. The philosopher exercises the highest (kratistēn) (1177a13, 19-20, 1177b34, 1178a5-6), divinist (theiotaton) (1177a16), and best (aristō) (1179a26) virtue, and in doing so engages in the most continuous (sunechestatē) (1177a21-22) and most pleasant

theological reasons which would have obliged him to accept these complications which are necessarily connected with the thesis of omniscience" ("Aristotle on SelfKnowledge," 503). 
(hēdistē) (1177a23, 1178a6) activity; of all human beings, he is the most self-sufficient (autarkestatos) (1177b1), the happiest (eudaimonestatos) (1178b23, 1179a31, 1177a6), and the most beloved by the gods (theophilestatos) (1179a30, 1178b22). In fact, the philosopher strives to attain immortality (athanatizein) (1177b33). This all corroborates the earlier finding that a philosopher does not need or want to associate with any human beings except the philosophical. Aristotle makes the similar observation in Book IX that the good man (philosophical and otherwise) not only does not mind being alone but enjoys it, at least in part because it offers an opportunity for reflection (1166a23-27); Aristotle also indicates in the Politics that a good man knows how to be a private individual (idiōtēs) (1277a24-25).

One thus wonders why Aristotle places his discussion of the philosopher in a section of the Nicomachean Ethics that serves as a transition to the Politics. Could it be that the philosopher represents-by his excellence, self-sufficiency, and solitude-the epitome of privacy, and that cities should not forget to provide for privacy? Privacy, being a moral, philosophical, and political good, provides a thematic link between ethics and politics narrowly understood. The good man enjoys it, the philosopher requires it, and the political order must provide it to cultivate not only diversity, a requirement of political unity (Pol 1261a23-30), but diversified excellence, a requirement of the best political order ( $P o l$ 1332a29-38, NE 1176b26-28).22 Mastering the violin, understanding a mathematical proof, running a marathon, and composing a poem may each conceivably be done in the company of others, but they do not require an audience and are not collective enterprises. Aristotle would disagree with Arendt that "neither education nor ingenuity nor talent can replace the constituent elements of the public realm, which makes it the proper place for human excellence." He would thus be surprised to find himself implicated as an advocate of this view:

Excellence itself, aretē as the Greeks, virtus as the Romans would have called it, has always been assigned to the public realm where

22 Thus Aristotle is, if anything, reacting against, not endorsing, the alleged view of his contemporaries and Homer that "the public realm ... was reserved for individuality"; see Hannah Arendt, The Human Condition (Chicago: University of Chicago Press, 1958), 41. 
one could excel, could distinguish oneself from all others. Every activity performed in public can attain an excellence never matched in privacy; for excellence, by definition, the presence of others is always required, and this presence needs the formality of the public, constituted by one's peers, it cannot be the casual, familiar presence of one's equals or inferiors. 23

In sum, Aristotle makes clear that human beings are not simply political animals (in the sense of inclined toward others) but, insofar as they have a divine element in them, also intensely private beings. "Happiness extends just so far as contemplation does" (NE 1178b28-29). Of course, "the happy person is a human being, and so will need external prosperity also" - that is, "bodily health, food, and [human] attention [tēn loipèn therapeian]" (1178b33-35). Nature compels the philosophical and all those who aspire to happiness to use the resources of both the public and the private. But in contrast to the noble citizen or ruler, who draws on the private to serve the public, the philosopher draws on the public to serve the private.

23 Ibid., 48-49. 